\title{
Some Reports of Paratethyan Ostracods from the Central Mediterranean Area
}

\author{
Temani $\mathbf{R}^{1 *}$, Francesco $\mathrm{S}^{2}$ and Khayati $\mathrm{AH}^{1}$ \\ ${ }^{1}$ The National Office of Mines, Tunisia \\ ${ }^{2}$ Department of Biological, University of Catania, Italy
}

\section{Short Communication}

Volume 2 Issue 1

Received Date: November 21, 2019

Published Date: December 10, 2019

*Corresponding author: Temani Rim, The National Office of Mines, Tunisia, Tel No: +21620733345; Email: rim.temani@yahoo.fr

\section{Abstract}

Uppermost Miocene stratigraphic sections have been sampled in Sicily and eastern Tunisia. Some of the stratigraphic levels contained in them are related to the continentalization phase ("Lago Mare") of the Mediterranean Basin, which occurred at the end of the Messinian Salinity Crisis. Within these levels, ostracod associations reflecting fresh or brackish water environments are reported here for the first time. Species considered to be Paratethyan in affinity lived in these environments. The discovery, both in Sicily and Tunisia, of species such as C agrigentina, A propinqua, and M. punctate, suggests that the Sicilian Channel did not prevent the migration of the non-marine fauna from NW to SE in the Paleomediterranean area during the Post Evaporitic Phase.

Keywords: Late Messinian; Lago Mare; Paratethys; Ostracods; Paleoenvironmental Evolution; Tunisia; Sicily

\section{Introduction}

The post evaporitic phase of the Late Messinian is characterized by intense continentalization of several parts of the Mediterranean Basin - the Lago Mare. Above the Messinian and pre-Messinian sequence, many large and shallow basins of fresh or brackish water formed. These environments were colonized by numerous organisms including ostracod species. Some of these species have a Paratethyan affinity, or rather; they are species that spread from the eastern Paratethyan Region to the western Paleomediterranean area [1]. This phenomenon was made possible by large and shallow water basins connecting with each other and with the large waterways of the Paratethyan region [2].

\section{Materials and Methods}

In order to verify the spread of paratethyan species in the central sector of the Mediterranean, we analyzed ostracod assemblages from two Late Messinian sections in Tunisia $\left(36^{\circ} 30^{\prime} 07^{\prime \prime} \mathrm{N} 10^{\circ} 44^{\prime} 46^{\prime \prime} \mathrm{E}\right.$ and $35^{\circ} 24^{\prime} 18^{\prime \prime} \mathrm{N}$ $\left.11^{\circ} 00^{\prime} 12^{\prime \prime} \mathrm{E}\right)$ and four sections in Sicily (38014'02.42" N; $15^{026} 14.11^{\prime \prime} \mathrm{E} ; 43 \mathrm{~m}$ a.s.l., $37^{\circ} 09^{\prime} 20.11^{\prime \prime} \mathrm{N} ; 1^{0} 42^{\prime} 33$. 81"E; 554 m a.s.l., $37^{0} 11^{\prime} 43.07^{\prime \prime} \mathrm{N} ; 1^{\circ} 42^{\prime} 04.90^{\prime \prime} \mathrm{E} ; 521 \mathrm{~m}$ a.s.l. and $37^{\circ} 08^{\prime} 53.71^{\prime \prime} \mathrm{N} ; 1^{0} 41^{\prime} 38.81^{\prime \prime} \mathrm{E} ; 435 \mathrm{~m}$ a.s.l.). The biostratigraphic analysis, paleoecological interpretations and geographical distributions of the ostracofauna led us to identify different environmental conditions of LagoMare events in the Central Mediterranean Basin [3].

\section{Results}

Two contemporary Lago-Mare events have been identified in Eastern Tunisia. The first one is represented by sedimentary facies containing brackish/lagoon species: Cyprideis agrigentina Decima, 1964 and Cyprideis torosa the second one is characterized by freshwater ostracod assemblages where the main taxa are Candona spp., Amnicythere propinqua, Ilyocypris gibba, 


\section{International Journal of Paleobiology \& Paleontology}

Mediocytherideis (Sylvestra) punctata Ligios et al., 2008, and Charophyte gyrogonites represented by Chara vulgaris Linnaeus, 1753 and Chara hispida Linnaeus, 1753 [4].

In Sicily, the sedimentary facies belonging to the post evaporitic period are called "Congeria" strata (marls containing oligohaline faunas) and "Arenazzolo" (reddish arkosic sands containing brackish or freshwater ostracods). From these contemporary levels, which correspond to two different sedimentation environments, an oligotypic ostracod fauna was extracted consisting of species belonging to the genera Tyrrhenocythere, Loxoconcha and Cyprideis. Among them, Loxoconcha muelleri and Cyprideis anlavauxensis Carbonnel, 1979 are reported for the first time from Sicily here.

\section{Discussion and Conclusion}

Our study has shown that, during the Post Evaporitic Phase of the Late Messinian, analogous ostracod species were present in Sicily and Tunisia. These species reflect a shallow water marine-transitional environment (internal lagoon) characterized by salty, brackish oligohaline water, with the addition of fluvial lacustrine water [5-7].

Species that can be considered of Paratethyan origin lived in these environments. Indeed, the discovery, both in Sicily and Tunisia, of species such as C. agrigentina, $A$. propinqua, and M. punctata, suggests that the Sicilian Channel did not prevent the migration of the non-marine fauna from NW to SE in the Paleomediterranean area during the Post Evaporitic Phase (Figures 1-3).
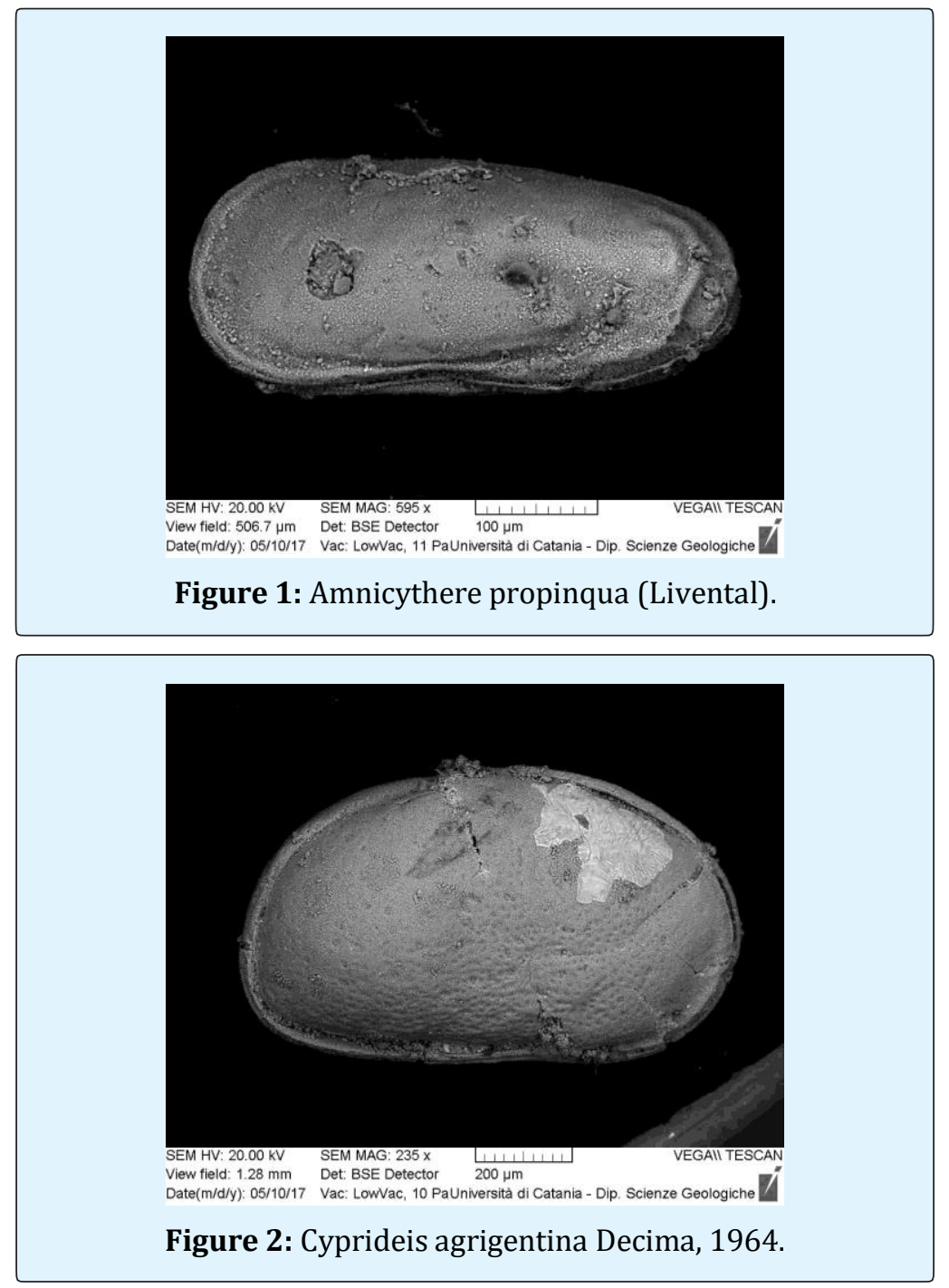

Temani R, et al. Some Reports of Paratethyan Ostracods from the Central 


\section{International Journal of Paleobiology \& Paleontology}

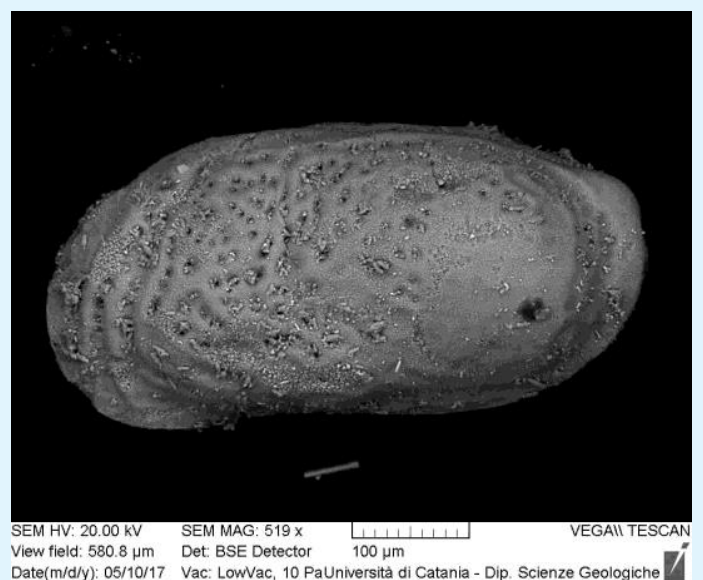

Figure 3: Mediocytherideis (Sylvestra) punctata Ligios, et al.

\section{References}

1. Baak V, Christiaan GC, Stoica M, Grothe A, Aliyeva E, et al. (2016) Mediterranean-Paratethys connectivity during the Messinian salinity crisis: The Pontian of Azerbaijan. Global and Planetary Change 141: 63-81.

2. Gliozzi E, Rodriguez LJ, Nachite D, Martin RM, Bekkali $R$ (2005) An overview of Neogene brackish leptocytherids from Italy and Spain: Biochronological and palaeogeographical implications. Palaeogeography, Palaeoclimatology, Palaeoecology 225(1-4): 283301.

3. Gliozzi E, Ceci ME, Grossi F, Ligios S (2007) Paratethyan ostracod immigrants in Italy during Late Miocene. Geobios 40(3): 325-337.

4. Gliozzi E, Grossi F (2008) Late Messinian Lago-mare ostracod palaeoecology: a correspondence analysis approach. Palaeogeography, Palaeoclimatology, Palaeoecology 264(3-4): 288-295.

5. Sciuto F, Baldanza A, Temani R, Privitera G (2018) New reports of Paratethyan ostracods affinity from the Mediterranean Basin (Sicily, Italy). Palaeontologia Electronica, pp: 1-19.

6. Temani R, Ammar Khayati H, Sciuto F (2018) New reports of Messinian Lago-Mare episodes from Tunisia: paleoenvironmental implications. First Conference of the Arabian Jouurnal of Geosciences: Hammamet, Tunisia, pp: 69-72.

7. Zhang Z, Khelifi N, Mezghani A, Heggy E (2018) Patterns and mechanism of climate, paleoclimate and paleoenvironmental changes from low- latitude regions. Procedings of the $1^{\text {st }}$ Springer conference of the Arabian Journal of Geosciences (CAJG) Earth Sciences \& Geography, pp: 19-21. 